\title{
Keabsahan Akad Jual Beli Online Muslim Kelas Menengah Kota Yogyakarta Pasca Pandemi Covid-19
}

\author{
Muzalifah \\ IAIN Palangka Raya \\ muzalifah@iain-palangkaraya.ac.id
}

\begin{abstract}
This study aims to determine the validity of the online buying and selling contract after the Covid-19 pandemic. Online buying and selling transactions are increasingly prevalent and have become superior after the Covid-19 pandemic. One of the factors is the government ban on crowds and encouragement to always maintain a safe distance to avoid Covid-19. This study uses a quantitative approach. The data collection technique used a questionnaire distributed to 45 respondents who carried out buying and selling online after the Covid-19 pandemic. Meanwhile, the data analysis used percentages. The results of the study found that only $8.9 \%$ of 45 respondents stated that they were buying and selling online to avoid the spread of Covid-19, 22.2\% of them stated that online buying and selling was profitable, and $26.7 \%$ for easier marketing. While the rest said that buying and selling online was done to save business capital and as a side job. According to Islamic law, there is no prohibition on buying and selling activities after the Covid-19 pandemic as long as it does not conflict with Islamic teachings. The contract in the sale and purchase is valid if it meets the requirements and is in harmony according to Islamic law. The application of khiyar rights in online buying and selling after the Covid-19 pandemic is important to implement. This is done to avoid a loss to one of the parties after the transaction process has taken place.
\end{abstract}

Keywords: Buying and selling online, Covid-19 Pandemic, Islamic Economic Law

\begin{abstract}
Abstrak
Penelitian ini bertujuan untuk mengetahui bagaimana keabsahan akad jual beli online pasca pandemi Covid-19. Transaksi jual beli online kian marak dan menjadi primadona pasca pendemi Covid-19. Salah satu faktornya yaitu adanya larangan dari pemerintah untuk melakukan kerumunan dan anjuran untuk senantiasa menjaga jarak aman agar terhindar dari Covid-19. Penelitian ini menggunakan pendekatan kuantitatif. Teknik pengumpulan data menggunakan angket yang disebar kepada 45 responden yang melaksanakan jual beli online pasca pandemi Covid-19. Sementara analisis data menggunakan persentase. Hasil penelitian menemukan bahwa, hanya $8,9 \%$ dari 45 reponden yang menyatakan mereka melakukan jual beli online untuk menghindari penyebaran Covid-19, 22,2\% diantaranya menyatakan karena jual beli online menguntungkan, dan 26,7\% untuk memudahkan pemasaran. Sementara sisanya mengatakan bahwa jual beli online dilakukan untuk menghemat modal usaha dan sebagai pekerjaan sampingan. Menurut hukum Islam, tidak ada larangan untuk melakukan kegiatan jual beli pasca pandemi Covid-19 selama tidak bertentangan dengan ajaran Islam. Akad dalam jual beli tersebut sah apabila memenuhi syarat serta rukun akad menurut hukum Islam. Penerapan hak khiyar dalam jual beli online pasca pandemi
\end{abstract}


Covid-19 penting untuk diterapkan. Hal tersebut dilakukan untuk menghindari kerugian pada salah satu pihak setelah proses transaksi berlansung.

Kata kunci: Jual beli online, Pandemi Covid-19, Hukum Ekonomi Syariah

\section{PENDAHULUAN}

Jual beli merupakan aktivitas yang tidak dapat dihindarkan dalam kehidupan sehari-hari. Aktivitas tersebut dilakukan untuk memenuhi segala macam sebutuhan manusia baik sandang maupun pangan. Oleh karena itu, segala macam bentuk jual beli dapat dengan mudah dijumpai dimanapun berada, baik di kota maupun di desa dan dari yang berbentuk tradisional hingga yang modern. Namun ketika pandemi Covid-19 sedang melanda, fenomena jual beli mengalami perubahan. Ketika berbelanja di Pasar tradisional misalnya, seseorang harus memakai alat pelindung diri, seperti masker dan menjaga jarak aman. Selain itu, ketakutan untuk melakukan transaksi tatap muka sebagaimana layaknya terjadi pada pasar tradisional membuat pasar tradisional sepi pembeli. Tidak hanya pasar tradisional, pasar modern juga mengalami hal yang sama.

Larangan untuk melakukan kerumunan dan keinginan untuk tidak melakukan aktivitas diuar rumah membuat ekonomi masyarakat pada umumnya menjadi kurang stabil. Banyak yang kehilangan pekerjaan karena terpaksa harus dirumahkan, pasar-pasar sepi dari pengunjung, usaha dibidang jasa seperti perhotelan bahkan banyak yang ditutup untuk sementara. Namun disebalik itu, muncul usahawan-usahawan baru yang sukses mengembangkan usahanya melalui pitur online seperti facebook, istagram dan youtube, sehingga belakangan ini bisnis online menjadi yang poluler ketika pandemi Covid-19.

Islam tidak melarang umatnya untuk melakukan kegiatan muamalah selama tidak ada dalil yang melarang, salah satu adalah bisnis online. Namun tetap harus berpegang teguh kepada prinsip-prinsip Islam, diantaranya adalah kejujuran dan amanah. Amanah dalam arti tidak mencederai kepercayaan pembeli kepada penjual. Demikian halnya dengan jual beli online pasca pandemi Covid-19.

Berdasarkan latar belakang tersebut, maka yang menjadi pertanyaan penelitian adalah bagaimanana praktik jual beli online muslim kelas menengah pasca pandemi Covid-19 dan bagaimana keabsahan akad jual beli online muslim kelas menengah pasca pandemi Covid-19. Dengan demikian yang menjadi tujuan penelitian adalah untuk memetakan praktik jual beli online muslim kelas menengah pasca pandemi Covid-19 dan menganalisis keabsahan akad jual beli online muslim kelas menengah pasca pandemi Covid-19. 


\section{KAJIAN LITERATUR}

Kajian tentang jual beli menurut hukum Islam sudah dilakukan oleh beberapa penulis sebelumnya, antara lain oleh Shobirin (Shobirin, 2015), Muhammad Yunus dkk (Yunus, Satria, \& Shofia, 2018), Siswadi (Siswadi, 2013), dan Mochammad Nuril Misbach et al (Misbach, Nafik, Ryandono, \& Prasetyo, 2019), Retno Dyah Pekerti dan Eliada Herwiyanti (Pekertti \& Herwiyanti, 2018), Munir Salim (Salim, 2017), (Hana, 2020), dan Wati Susiawati ( Susiawati, 2017). Sementara tentang strategi jual beli pada masa pandemi dilakukan oleh Muhammad Aminul (Salam, 2020) dan Mochammad Al Ikhsan (Ikhsan, 2020).

Beberapa penulis tersebut di atas memiliki kesamaan dengan kajian yang penulis lakukan, yaitu tentang jual beli dan dampak ekonomi yang ditimbulkan oleh pandemi Covid-19. Namun, yang membedakan penelitian ini dengan sebelumnya adalah penelitian ini lebih fokus kepada praktik bisnis online pedagang muslim kelas menengah Yogyakarta pasca pandemi Covid-19. Berdasarkan paparan di atas, penulis bermaksud untuk memetakan praktik jual beli online muslim kelas menengah pasca pandemi Covid-19 dan bagaimana keabsahan akad jual beli online muslim kelas menengah pasca pandemi Covid-19.

\section{METODE PENELITIAN}

Penulis menggunakan pendekatan kuantitatif. Sumber data penelitian adalah pedagang yang melakukan jual beli online di Kota Yogyakarta pasca pandemic Civid-19. Metode pengumpulan data menggunakan angket yang disebar kepada 45 responden. Analisis data menggunakan rumus persentase dari keseluruhan jumlah reponden. Dalam menentukan keabsahan akad dalam jual beli online pasca pandemi Covid-19, peneliti menggunakan teori akad dalam hukum ekonomi syariah sebagai pisau analisisnya. Secara toeritis, tulisan ini bermaksud untuk menambah khazanah keilmuan dibidang hukum ekonomi syariah. Sementara secara praktis, tulisan ini dapat menjadi sumber informasi bagi pedagang untuk mengembangkan bisnis online pada masa pandemi Covid-19.

\section{PEMBAHASAN}

1. Praktik jual beli online muslim kelas menengah pasca pandemi Covid19 pada bulan Desember 2019, bermunculan sejumlah kasus pneumonia dengan penyebabnya tak diketahui yang memiliki gejala demam, rasa letih, batuk, dan kesulitan bernapas sebagai gejala utama, yang terjadi di Wuhan dalam waktu singkat. Patogen penyakitnya secara cepat diidentifikasi sebagai virus corona baru, yang kemudian dikonfirmasi oleh Organisasi Kesehatan Dunia (WHO). WHO menamakan virus itu 2019-nCoV sementara Komite Internasional Taksonomi Virus (ICTV) 
menyebutnya SARS-Cov-2; dan pneumonia yang disebabkan oleh infeksi virus disebut pneumonia coronavirus baru (COVID-19) oleh WHO (Zhou, 2020: 16).

Pandemi Covid-19 berdampak pada sosial-ekonomi masyarakat, sebagaimana yang disampaikan pada berbagai webinar antara lain oleh Mochammad Firman Hidayat(Hidayat, 2020), P. Agung Pambudhi(Pambudhi, 2020) dan Pande Made Kutanegara(Kutanegara, 2020). Dampak tersebut juga ditulis pada media cetak seperti majalah dan buku antara lain oleh Mahandis Yoanata Thamrin(Thamrin, 2020), Wang Zhou(Zhou, 2020), Fikri Muhammad(Muhammad, 2020), Muhamad Wildan \& Wike D. Herlinda(Wildan \& Herlinda, 2020). Kajian tentang dampak Pandemi Covid-19 terhadap ekonomi dan sosial juga telah dilakukan oleh beberapa organisasi internasional, seperti CCSA (Committee for the Coordination of Statistical Activities (CCSA), 2020), McKinsey \& Company (Company, 2020), United Nations (Nations, 2020), EOCD (EOCD, 2020) dan World Economic Forum (Forum, 2020).

Salah satu kebijakan yang dilakukan oleh pemerintah, baik dalam negeri maupun luar negeri untuk menghindari penyebaran virus, yaitu melakukan Pembatasan Sosial Skala Besar (PSSB). Kebijakan tersebut berdampak pada aktivitas ekonomi di Indonesia (M. F. Hidayat, 2020: 6).

Dampak ekonomi dirasakan oleh masyarakat yang berprofesi sebagai pedagang, baik perupa barang maupun jasa. Namun disebalik ini, memunculkan usahawan-usahawan baru yang yang aktif di dunia maya. Kontraksi ekonomi, sebagaimana terlihat pada grafik dibawah ini, tidak berpengaruh signifikan kepada penghasilan mereka yang melakukan jual beli online di dunia maya.

Sebagian besar yang melakukan jual beli online pasca pendemi adalah muslim kelas menengah. Pernyataan ini berdasarkan pada hasil survei yang penulis lakukan kepada 45 responden yang melakukan jual beli online pasca pandemi Covid-19. Dari 45 responden tersebut, 93,3\% diantaranya beragama Islam.

Salah satu faktor yang ikut mendukung praktik jual beli online pada masyarakat muslim kelas menengah adalah semangkin maraknya perangkat gadget, smartphone, atau tablet yang banyak digunakan oleh muslim kelas menengah (Yuswohadi, 2015: 270). Secara demografi, hampir $76 \%$ pengguna internet di Indonesia umurnya berada dibawah 35 tahun, sedangkan sisinya hanya mencapai $13 \%$. Dengan kata lain, penggerak pengguna internet adalah anak muda. Mereka aktif dimedia sosial, senang berbelanja online, nonton video di youtube dan gonta ganti smartphone. Penyataan tersebut merupakan peluang bagi muslim 
kelas menengah untuk mengembangkan bisnis jual beli online, lebihlebih lagi pasca pendemi Covid-19 dimana seseorang dihimbau untuk tetap menjaga jarak.

Berdasarkan hasil survei, 45 responden yang memanfaatkan jual beli online pasca pandemi Covid-19, 88,9\% diantaranya melakukan jual beli secara online, sedangkan sisanya melakukan jual beli dengan cara offline. Pengaruh jual beli online terhadap penghasilan muslim kelas menengah Pasca Pandemi Covid-19 sangat signifikan, sebagaimana gambar di bawah ini, 95,6\% dari semua responden menyatakan bahwa penghasilan mereka bertambah ketika melakukan jual beli secara online.

Terdapat beberapa platform digital yang digunakan oleh pedagang untuk meningkatkan penjualan pasca pandemi Covid-19, antara lain: arketplace, Facebook, Google My Business, Instagram, dan Website (Fariz Harisuddin, 2020 : 39). Dari beberapa platform digital tersebut, berdasarkan hasil survei penulis, dari 45 responden, platform digital yang banyak digunakan oleh muslim kelas menengah untuk melakukan jual beli online pasca pandemi Covid-19 adalah facebook, yakni mencapai 95,6\%, kemudian diikuti oleh Instagram (28,9\%), shoppee $(24,4 \%)$, whatsAPP $(24,4 \%)$, lain-lain $(22,3 \%)$.

Muslim kelas menengah melakukan bisnis jual beli Online Pasca Pandemi Covid-19 disebabkan oleh beberapa faktor, antara lain: transaksi online lebih mudah dan menguntungkan (22,2\%), memudahkan pemasaran (26,7 \%), Menghemat modal usaha (13,3\%), dan menghidari penyebaran Covid-19 (8,9\%), lainnya menjadikan bisnis jual beli online sebagai pekerjaan sampingan $(6,7)$. Adapun produk yang diperjualbelikan juga beraneka ragam, mulai fashion $(31,1 \%)$, produk olahan $(15,6 \%)$, perabot rumah tangga $(11,1 \%)$, barang basah $(11,1 \%)$, pulsa elektronik $(8,9 \%)$, dan produk kesehatan $(8,9 \%)$. Mereka umumnya melakukan jual beli online Pasca Pandemi Covid-19 diberbagai tempat, seperti: dirumah $(62,2 \%)$, pasar $(13,3 \%)$, toko $(4,4 \%)$, lain-lain (20\%).

2. Keabsahan akad jual beli online muslim kelas menengah pasca pandemi Covid-19

Akad berasal dari bahasa Arab, 'aqada artinya mengikat atau mengokohkan. Secara etimologi, akad berarti ikatan, mengikat atau alrabath, yang maksudnya menghimpun atau mengumpulkan dua ujung tali yang ujungnya saling terikat, hingga keduanya tersambung menjadi seutas tali. Dengan demikian, akad merupakan peristiwa hukum antara dua pihak yang berisi ijab dan qabul yang sah menurut syara' dan menimbulkan akibat hukum(Fariz Harisuddin, 2020 : 39). Menurut Wahbah al-Zuhaili dan Ibnu Abidin yang dimaksuk dengan akad secara terminologi adalah pertalian antara ijab dan qabul sesuai dengan 
kehendak syariah (Allah dan Rasul-Nya) yang menimbulkan akibat hukum pada objeknya(Fariz Harisuddin, 2020 : 39).

Dari segi kecakapan untuk melakukan akad, manusia dapat terbagi atas tiga kategori, yaitu: (1) manusia yang tidak dapat melakukan akad apapun, seperti halnya orang-orang yang cacat jiwa, mental dan anak kecil yang belum mumayyiz, (2) manusia yang dapat melakukan akad tertentu, seperti anak yang sudah mumayyiz (sudah dapat membedakan yang baik dan yang buruk) akan tetapi belum baligh, dan (3) manusia yang dapat melakukan seluruh akad, yaitu yang sudah memenuhi syarat-syaratnya sebagai seorang mukallaf (Fariz Harisuddin, 2020 : 39).

Berdasarkan hasil survei yang penulis lakukan, rata-rata pedagang yang malakukan bisnis online sudah berumur diatas 18 tahun. Oleh karena itu, jika dilihat dari kecapakan dalam membuat akad, maka pedagang tersebut sudah tergolong kepada mukallaf yang dapat melakukan seluruh akad. Pernyataan ini dapat disandarkan kepada tindakan manusia dalam figh al-muamalat pada prinsipnya dianggap sah, kecuali ada beberapa halangan yaitu: masih dibawah umur (safih/minors), gila (junun/insanity), ediot ('atah/idiocy), boros atau berlebih-lebihan (safah/prodigality), kehilangan kesadaran (igma'/unconsciousness), tertidur dalam keadaan tidur gelap (nawm/sleep), dan memiliki kerusakan akal, kehilangan akal atau kekurangan akal (awarid mukhtasabah/acquired defect) (Fariz Harisuddin, 2020 : 39).

Bisnis online memang tidak dilakukan dengan tatap muka (antara penjual dan pembeli tidak dapat bertemu secara lansung). Namun satu hal yang dapat mengikat mereka adalah kepercayaan satu sama lain (Hana, 2019). Transaksi jual beli tersebut dapat terhindar dari cedera selama mereka menerapkan asas-asas akad syariah menurut Bab II, Pasal 21 Kompilasi Hukum Ekonomi Syariah (KHES), antara lain: ikhtiyari/sukarela, amanah/menepati janji, ikhtiyati/kehati-hatian, luzum/tidak berubah, saling menguntungkan, taswiyah/kesetaraan, transparansi, kemampuan, taisir/kemudahan, iktikat baik, dan sebab yang halal. Agar pelaksanaan akad sesuai dengan asas-asas dalam hukum ekonomi syariah, dalam melaksanakan akad wajib rukun dan syarat akad(Fariz Harisuddin, 2020 : 39).

Fathurahman Djamil menyatakan setidaknya ada lima macam asas yang harus ada dalam suatu akad, antara lain: kebebasan (alhurriyyah), kesamaan dan kesetaraan (al-musawah), keadilan (al-'adalah), kerelaan (al-ridha), dan tertulis (al-kitabah) (Fariz Harisuddin, 2020 : 39). Jika salah satu dari asas tersebut tidak terpenuhi maka akadnya menjadi cacat, rusak, bahkan batal menurut hukum Islam. 
Terdapat hal-hal yang dapat merusak akad dalam jual beli online selain dari mengabaikan asas-asas dalam akad, antara lain: adanya unsur keterpaksaan (al-ikrah), kekeliruan pada objek akad (ghalath), penipuan (tadlis) ,dan tipu muslihat (taghir). Ketentuan tersebut juga terdapat dalam Kitab Undang-Undang Hukum Perdata (KUHP) yang menyatakan bahwa suatu akad dapat dianggap sah jika memenuhi empat syarat, yakni: adanya kata sepakat secara sukarela dari kedua belah pihak (teostemming), kecakapan atau kedewasaan (behwaamheid), mengenai pokok atau objek akad tertentu (bepaalde onderwerp), dan atas sebab yang diperbolehkan (geoorloofdeoorzaak) (Fariz Harisuddin, 2020 : 39).

Jika dilihat dari bentuknya, akad jual beli online termasuk kedalam akad mu'athah. Akad mu'athah yaitu mengambil dan memberikan dengan tanpa perkataan (ijab dan qabul), sebagaimana seseorang membeli sesuatu yang telah diketahui harganya, kemudian ia mengambilnya dari penjual dan memberikan uangnya sebagai pembayaran(Fariz Harisuddin, 2020 : 39). Dalam hal ini, akad terjadi dalam bentuk perbuatan biasa disebut sebagai al-'aqad bi al-mu'athah. Dari sisi mekanismenya sama, namun berbeda dari sisi praktisnya, "mengambil" dalam jual beli online adalah membeli, namun barang masih belum ditangan, karena masih harus melalui proses transfer dan pengiriman barang ke tempat tujuan. Akad jual beli online berakhir setelah barang terkirim dan tidak ada komplen dari pembeli atau terpenuhinya tujuan akad.

Terdapat beberapa hal yang dapat menyebabkan berakhirnya akad selain dari terpenuhinya tujuan akad (tahqiq gharadh al-'aqad), antara lain: (1) pembatalan (fasakh), putus demi hukum (infisakh), kematian, dan ketidakizinan ('aqad al-ijazah) dari pihak yang memiliki kewenangan dalam mengurus akad muquf (akad yang keabsahannya bergantung pada pihak lain (Fariz Harisuddin, 2020 : 39).

a. Jual beli online menurut hukum Islam

Menurut bahasa, jual beli artinya menarik benda dari milik (para pihak) dengan jalan pertukaran(Fariz Harisuddin, 2020 : 39). Secara global, jual beli termasuk dalam aktifitas mubah selama tidak ada hal-hal yang dapat merusaknya seperti adanya unsur garar, penipuan, kecurangan, dan paksaan. Pedagang dapat memilih metode atau cara bertransaksi sesuai dengan keinginannya. Inovasi dan kreatifitas para pelaku usaha dari masa ke masa menghasilkan sistem jual beli yang dirasa lebih efektif dan efisien, sehingga muncul berbagai jenis jual beli yang berkembang di masyarakat(Fariz Harisuddin, 2020 : 39).

Dasar hukum dianjurkannya untuk melakukan jual beli terdapat dalam firman Allah Q.S Al-Baqarah ayat 275, artinya: 
"Allah telah menghalalkan jual beli dan mengharamkan riba...", dan Q.S An-Nisa ayat 29, artinya: "Hai orang-orang yang beriman, janganlah kamu saling memakan harta sesamamu dengan jalan yang batil, kecuali dengan jalan perniagaan yang berlaku dengan suka sama suka diantara kamu, dan janganlah kamu membunuh dirimu, sesungguhnya Allah maha penyayang kepadamu." Hadis Rasulullah SAW dari Suhaib Arrumi r.a. bahwa Rasulullah SAW bersabda: "Tiga hal yang didalamnya terdapat keberkahan: jual beli secara Tangguh, mudharabah dan mencampurkan gandum dengan tepung untuk keperluan rumah, bukan untuk dijual." (HR. Ibnu Majah) (Fariz Harisuddin, 2020 : 39).

Dasar hukum lainnya yang berkaitan lansung dengan jual beli adalah hadis riwayat Ibnu Majah dan Baihaqi, artinya "jual beli itu sah bila saling merelakan", dan hadis riwayat Al-Hakim, artinya "Nabi SAW, ditanya tentang mata pencaharian yang paling baik, Beliau menjawab, seorang bekerja dengan tangannya dan seluruh jual beli yang mabrur".

Jual beli online seyogyanya merupakan jual beli yang mengatasnamakan kepercayaan baik penjual maupun pembeli. Terlebih pada masa pendemi, dimana antara penjual dan pembeli dianjurkan untuk tetap menjaga jarak dan menghindari kerumunan. Dalam jual beli online, antara penjual dan pembeli tidak melakukan tatap muka secara lansung (tatap muka hanya dapat dilakukan secara virtual). Oleh karena itu, satu hal yang dapat memelihara kepercayaan tersebut adalah adanya sikap sikap 'antaradhin (Saebeni, 2018:72).

Dengan demikian baik penjual maupun pembeli dapat menghindari jual beli yang dilarang dalam Islam, seperti: (1) jual beli gharar, (2) jual beli barang-barang haram dan najis, (3) jual beli mulamasah, (4) jual beli mukhadharah, (5) jual beli munsbadzah, (6) jual beli muzabanah atau muhaqalah, (7) jual beli satu barang dengan dua harga, dan (8) jual beli dengan mekanisme judi (maisir) (Saebeni, 2018:74).

b. Akad dalam jual beli online pasca pandemi Covid-19

Jual beli online pada masa pandemi termasuk jual beli yang sah (shahih) apabila telah memenuhi syarat dan dan rukun akad. Rukun akad meliputi pelaku, objek, dan ijab dan qabul. Apabila rukun terpenuhi maka jual belinya sah (Fauzia \& Riyadi, 2015:224). Sementara syarat bagi penjual dan pembeli pada umumnya meliputi: (1) sudah baliqh, sehat lahiriah dan batiniah, dan (2) atas kehendak sendiri, tidak ada unsur paksaaan. Sementara syaratsyarat barang yang diperjualbelikan meliputi: (1) barang yang suci 
dan mungkin dapat disucikan, (2) barang yang dapat memberikan manfaat satu sama lain, (3) tidak mengaitkan barang dengan syarat tertentu, dan (4) tidak dibatasi dengan waktu (Saebeni, 2018:73).

Kesepakatan para pihak dalam jual beli online dapat saling menguntungkan apabila terhindar dari beberapa hal, yakni kesalahan atau kekeliruan objek, adanya paksaan kepada salah satu pihak, dan adanya penipuan (Suadi, 2018:194). Hal ini seyogyanya senantiasa dijaga agar jual beli yang dilakukan mendapat berkah, karena tujuan dari Islam adalah untuk mendapatkan kebahagiaan dunia dan akhirat.

Syarat-syarat transaksi akad jual beli online khususnya dapat diturunkan lagi menjadi beberapa hal, antara laini: (1) penjual harus jujur (terbuka) mengenai modal dan keuntungan kepada pembeli, (2) akad harus bebas dari riba, (3) penjual harus menjelaskan kepada pembeli bila terjadi cacat atas barang sesudah pembelian, (4) penjual harus menyampaikan semua hal yang berkaitan dengan pembelian, dan (5) akad pertama harus sah sesuai dengan rukun yang ditetapkan. Jika pada syarat 1,3, dan 4 tidak terpenuhi maka pembeli memiliki hak opsi (khiyar) antara lain: pembeli tetap melanjutkan seperti apa adanya, pembeli kembali kepada penjual dan manyatakan ketidaksetujuannya atas barang yang dijual, dan membatalkan akad(Suadi, 2018:194).

Hak khiyar dalam jual beli online khususnya dimaksudkan untuk menjamin agar akad benar-benar terjadi atas kerelaan penuh para pihak yang bersangkutan, dimana kerelaan merupakan salah satu asas bagi sahnya suatu akad. Hak khiyar menjadi penting dalam jual beli online, terlebih pada masa pendemi agar salah satu dari para pihak tidak dirugikan. Khiyar dalam jual beli terdiri dari beberapa macam, antara lain: khiyar syarath, khiyar ta'yin, khiyar 'aib, khiyar arru'yah, dan khiyar majlis (Manan, 2012:99).

Khiyar syarath adalah hak untuk memilih antara melansungkan atau membatalkan akad yang telah terjadi, bagi masing-masing, atau salah satu pihak dalam waktu tertentu. Khiyar syarath hanya berlaku dalam akad yang bersifat mengikat kedua belah pihak seperti jual beli, sewa menyewa, perserikatan dagang dan jaminan utang. Salah satu tujuan khiyar syarath yaitu untuk memelihara hak-hak para pihak dari unsur penipuan yang mingkin terjadi.

Pada jual beli online, khiyar syarath umumnya berlaku pada barang-barang elektronik, yang diperjualbelikan secara online. Salah satu ciri yang menunjukkan bahwa pada proses transaksi tersebut terdapat khiyar syarath adalah adanya ungkapan, misalnya "apabila 
terjadi kerusakan tanpa disengaja dalam waktu satu minggu, maka barang dapat dikembalikan atau ditukar dengan yang baru".

Khiyar ta'yin adalah hak pilih bagi pembeli dalam menentukan barang yang menjadi objek akad. Khiyar ta'yin dibolehkan apabila identitas barang yang menjadi objek akad belum jelas. Tujuan dari khiyar ta'yin yaitu untuk menghindari agar tidak terjadi terhadap sesuatu yang tidak jelas (majhul). Pada jual beli online, khiyar ta'yin dapat dijumpai di toko online shop seperti Shoppee. Pada toko tersebut umumnya mengikat kepercayaan pembeli dengan memberikan pilihan dan sistem cod. Misal jual beli produk fashion seperti pakaian yang umumnya barang dikirim dalam bentuk dua paket, sehingga pembeli dapat memilih sesuai dengan keinginannya.

Khiyar 'aib, adalah hak untuk membatalkan atau melansungkan akad bagi kedua belah pihak yang mengadakan akad, apabila terdapat suatu cacat pada objek akad dan cacat ini tidak diketahui pemiliknya ketika akad berlansung. Khiyar 'aib menurut pendapat jumhur ulama berlaku sejak diketahuinya cacat pada barang yang diperjualbelikan dan dapat diwarisi oleh ahli waris pemilik hak khiyar (Manan, 2012:101).

Salah satu bentuk dilaksanakannya khiyar 'aib dalam proses jual beli online adalah ketika pedagang membuat pernyataan apabila terdapat kecacatan tanpa sepengatahuan penjual pada barang yang diperjualbelikannya, maka pembeli dapat memilih membatalkan atau minta diganti dengan yang baru. Hal ini dapat menyakinkan pembeli untuk membeli barang dagangannya dan merupakan salah satu dari trik untuk menggaet pembeli dalam jual beli online.

Khiyar ar-ru'yah adalah hak pilih bagi pembeli untuk menyatakan berlaku atau batal jual beli yang ia lakukan terhadap suatu objek yang belum ia lihat ketika kontrak berlansung. Dasar hukum khiyar ar-ru'yah adalah hadis Riwayat al-Daruqutni dari Abu Hurairah r.a, artinya: "siapa yang membeli sesuatu yang belum ia lihat, makai a berhak khiyar apabila telah melihat barang itu". Salah satu yang dapat menyebabkan berakhirnya khiyar 'aib yaitu pembeli menunjukkan kerelaannya melansungkan jual beli baik melalui pernyataan atau tindakan (Manan, 2012:103).

Hak khiyar ar-ru'yah pada jual beli online dapat dilakukan pada barang-barang dalam bentuk kemasan, seperti jual beli makanan yang sudah dikemas dalam bentuk kaleng atau botol. Pembeli mempunyai hak pilih jika barang barang yang terdapat 
dalam kemasan tersebut tidak sesuai dengan yang telah ditetapkan dalam akad.

Khiyar majlis adalah hak pilih bagi kedua belah pihak yang berkontrak untuk meneruskan akad selama keduanya masih dalam majlis akad. Khiyar majlis berlaku dalam kontrak yang bersifat mengikat kedua belah pihak seperti jual beli dan sewa mengewa. Dasar hukum khiyar majlis yang diriwayatkan oleh Al-Bukhari dan Muslim dari Abdullah Ibnu Umar r.a, yaitu "apabila dua orang melakukan kontrak jual beli, maka masing-masing pihak mempunyai hak pilih, selama keduanya berlum berpisah padan".

Khiyar majlis pada jual beli online dapat dilakukan ketika proses transaksi, dimana antara penjual dan pembeli berada dalam majlis akad. Majlis akad dalam hal ini tidak harus bertemu fisik antara penjual dan pembeli dalam suatu tempat, berada dalam satu jaringan internet (misal facebook, Instagram dan whatsapp) juga dapat dikatakan sebagai majlis. Dalam hal ini antara penjual dan pembeli dapat membatalkan atau melanjutkan akad selama proses transaksi tersebut masih berlansung.

\section{KESIMPULAN}

Dibalik status primadona atas jual beli online pasca pandemi Covid-19 muslim kelas menengah Kota Yogyakarta dilatarbelakangi oleh beberapa faktor, diantaranya adalah kemudahan dalam melakukan pemasaran, keuntungan yang menjanjikan, menghemat modal usaha, dan menghindari penyebaran Covid-19. Namun hanya sebagian kecil yang melakukan jual beli online pasca pandemi Covid-19 dikarenakan untuk menghindari penyebaran Covid-19. Dalam hukum Islam, pelaksanaan akad jual beli online pasca pandemi Covid-19 sah apabila mememuhi syarat dan rukun akad meskipun tidak dilakukan dengan tatap muka. Selain itu, penerapan hak khiyar juga penting untuk dilakukan untuk menghindari kerugian pada salah satu pihak dalam transaksi jual beli online pasca pandemi Covid-19.

\section{DAFTAR PUSTAKA}

Committee for the Coordination of Statistical Activities (CCSA). (2020). How COVID-19 is Changing the World: a Statistical Perspective. UNCTAD.

Company, M. \&. (2020). Briefing Materials, Global Health and crisis response. McKinsey and Company.

EOCD. (2020). The impact of the coronavirus ( COVID-19) crisis on development finance. (June), 1-22.

Forum, W. E. (2020). Challenges and Opportunities in the Post-COVID-19 World.

Hana, K. F. (2019). Minat Beli Online Generasi Milenial: Pengaruh 
Kepercayaan dan Kualitas Layanan. BISNIS: Jurnal Bisnis Dan Manajemen Islam, 7(2), 203-216. Retrieved from http://journal.iainkudus.ac.id/index.php/bisnis/index

Hana, K. F. (2020). Keputusan Wanita Muslim Milenial Berwirausaha: Pengaruh Konsep Diri dan Lingkungan. At-Tijaroh: Jurnal Ilmu Manajemen Dan Bisnis Islam, 6(1), 23-36.

Hidayat, M. F. (2020). Strategi Penanggulangan Peningkatan Pengangguran dan Pemulihan Ekonomi Nasional: Perspektif Makroekonomi dan Jangka Menengah. Webinar.

Ikhsan, M. Al. (2020). Online Marketing Strategy Sebagai Solusi dikala Pandemi Covid-19.

Kutanegara, P. M. (2020). Penelitian Sosial dan Keagamaan : Antropolog di Masa Pandemi Pandemi : Webinar.

Manan, A. (2012). Hukum Ekonomi Syariah dalam Perspektif Kewenangan Peradilan Agama. Jakarta: Prenada Media Group.

Misbach, M. N., Nafik, M., Ryandono, H., \& Prasetyo, A. (2019). An Overview of Islamic Law Against Buying and Selling Sand-Land With a Liberation System (Case Study in Mount Wurung of Mojokerto Regency). $1(1), 6-19$.

Muhammad, F. (2020). Bergelut Melawan Pegebluk: Moral Cerita Para Penyintas Virus Mematikan di Episentrum Prahara. Akankah kita Menuai Panduan Hidup untuk Masa Depan atau Mengulang Kekacauan? National Geographic Indonesia.

Nations, U. (2020). Shared Responsibility, Global Solidarity: Responding to The Socio-Economic Impacts of Covid-19. (March).

Pambudhi, P. A. (2020). Strategi Dunia Usaha Menghadapi Krisis dan Upaya untuk Menyesuaikan Proses Bisnis Pasca Pandemi. Webinar.

Pekertti, R. D., \& Herwiyanti, E. (2018). Transaksi Jual Beli Online dalam Perspektif Syariah Madzhab Asy-Syafi'i. Jurnal Ekonomi, Bisnis, Dan Akuntansi (JEBA), 20(02), 1-12.

Saebeni, B. A. (2018). Hukum Ekonomi Syariah \& Akad Syariah di Indonesia. Bandung: Pustaka Setia.

Salam, M. A. K. (2020). Perilaku Produksi di Tengah Krisis Global Akibat Pandemi Covid-19 dan Memanfaatkan Media Online Facebook sebagai Alternatif Pasar. 1-22.

Salim, M. (2017). Jual beli secara online menurut pandangan hukum islam. Al-Daulah, 6(2), 371-386.

Shobirin. (2015). Jual Beli dalam Pandangan Islam. Bisnis Dan Manajemen Islam, 3(1), 240-261.

Siswadi. (2013). Jual beli dalam perspektif islam. Jurnal Ummul Qura, III(2), 59-65.

Suadi, A. (2018). Penyelesaian Sengketa Ekonomi Syariah: Penemuan dan Kaidah 
Keabsahan Akad Jual Beli Online Muslim Kelas Menengah Kota Yogyakarta Pasca Pandemi Covid-19

Hukum. Jakarta: Prenada Media Group.

Susiawati, W. (2017). Jual beli dan dalam konteks kekinian. Jurnal Ekonomi Islam, 8(November 2017), 171-184.

Thamrin, M. Y. (2020). Kita Mulai Bosan. Akankah kita bertahan? (p. 3). p. 3. Intisari: Smart and Inspiring.

Wildan, M., \& Herlinda, W. D. (2020). Jangan sia-siakan anggaran. Bisnis Indonesia, (11814).

Yunus, M., Satria, F. H. F. R., \& Shofia, G. K. (2018). Tinjauan Fikih Muamalah Terhadap Akad Jual Beli dalam Transaksi Online pada Aplikasi Go-Food. Jurnal Ekonomi Dan Keuangan Syariah, 2(1), 134-146.

Yuswohadi. (2015). 8 Wajah Kelas Menengah. Jakarta: PT Gramedia Pustaka Utama.

Zhou, W. (2020). Buku Panduan Pencegahan Coronavirusl: 101 Tips Berbasis Sains yang Dapat Menyelamatkan Hidup Anda. Chief Physician of Wuhan Center For Disease Control and Prevention. 